\title{
ALGUMAS CONSIDERAÇÕES SOBRE A ESTÉTICA DO CARTAZ DE GUERRA NA EUROPA - 1914-1918
}

\author{
Prof. Dr. Vanessa Bortulucce
}

A proposta desta comunicação é realizar uma reflexão acerca dos elementos que constituem a estética do cartaz de guerra, considerando-se aqueles produzidos em virtude da eclosão da primeira Guerra Mundial (1914-1918) pelas nações européias envolvidas no conflito. Esta estética apresenta aspectos específicos devido a natureza de seu suporte: o cartaz, um dos instrumentos visuais mais fortes que se desenvolvem no seio da sociedade industrial a partir do século XIX, destaca-se dentro da chamada comunicação de massa, por ser um elemento vital de propaganda, ligado intimamente à dinâmica dos grandes centros urbanos.

A estampa é, pelo seu princípio, a multiplicação da imagem. Quanto maior o número de cartazes e melhor a logística da distribuição dos mesmos, mais eficaz será a difusão e a recepção da mensagem. Não é difícil compreender, portanto, a importância particular que o cartaz assume dentro da política, esta, possuidora de uma necessidade vital de multiplicar, difundir, "colar" na mente dos indivíduos a sua doutrina, a sua ideologia, a sua reivindicação.

O cartaz, em períodos de guerra, mostrou-se extremamente eficiente neste sentido. Dado os interesses em jogo e a causa em questão a guerra - o cartaz foi, pela primeira vez, utilizado numa escala até então nunca vista, de forma consciente e metódica pelos dirigentes das nações. O cartaz de guerra é, ao mesmo tempo, instrumento de propaganda, arma psicológica, mecanismo de manipulação das massas; neste sentido, a sua estética, sua apresentação visual, é pensada no sentido de atrair a atenção do espectador e transmitir, da forma mais precisa possível, a sua mensagem. Além da guerra propriamente dita, travava-se outra, simultaneamente: a guerra da propaganda, que é uma guerra toda ela particular, que envolve tanto civis como militares. Trata-se de uma guerra combatida a golpes de notícias falsas, fotomontagens, manifestos. Cada uma das partes acusa a outra de barbárie, enquanto os melhores talentos da gráfica se colocam a serviço do conflito.

O cartaz comporta simultaneamente um conteúdo funcional e outro estético. Entre ambos reside um espaço onde se aglomeram desejos, sensações e motivações múltiplas, que procura atender as expectativas da 
sociedade de massa. Reproduzido em grande escala, facilmente identificável nas ruas, nos postes e nos muros, o cartaz possui o desafio de transmitir uma mensagem para o espectador nos poucos segundos em que este o visualiza. A captação da mensagem pelo transeunte deve ser absorvida de forma instantânea, objetiva, sem espaço para dubiedades.

Neste sentido, os artistas gráficos destes cartazes - que poderiam ser totalmente anônimos ou notadamente reconhecidos - descobriram a eficácia emocional de um gesto bem construído, de um olhar bem delineado pelo pincel, a ponto de provocar no espectador um sentimento de incrível exclusividade - como se apenas para ele o cartaz foi produzido. Este pode ser a característica mais interessante do cartaz em geral, e que se acentua naquele produzido em tempos de guerra: sua produção, circulação e reprodução são pensados logicamente em termos de massa; contudo, o sucesso de sua mensagem (também pensado em termos coletivos), só pode ser obtido se a mesma é capaz de seduzir, em primeiro lugar, o indivíduo.

Os temas que predominavam nos cartazes variavam de país para país. Assim, no caso inglês, o alistamento manteve-se voluntário até 1916, e os cartazes tinham como principal tema esta questão do alistamento. $\mathrm{O}$ número de cartazes foi tão grande que o Museu Britânico optou por renunciar ao direito de receber um exemplar de cada impresso, em conseqüência do excessivo volume de depósitos.

$\mathrm{Na}$ França, o recrutamento era obrigatório, e não existia produção de cartazes para este fim, tendo a propaganda se concentrado sobre as organizações de assistência e empréstimos de guerra, na moral do exército e da população civil, e no uso racional dos recursos. Já os EUA concentram seus temas na questão dos empréstimos de guerra; o recrutamento obrigatório acontece a partir de 1917, ano em que marca sua entrada no conflito. A Primeira Guerra Mundial ofereceu as condições propícias à eclosão do cartaz contemporâneo: existia uma forte corrente contra a participação do país no conflito, e, por outro lado, estavam em jogo altos interesses econômicos dos EUA relacionados com os fornecimentos e empréstimos, principalmente aos países da Entente, concedidos desde o início da guerra. A maior parte dos cartazes norte-americanos, portanto, refere-se aos empréstimos de guerra, ao esforço de produção, à utilização racional dos recursos, às organizações de assistência e recrutamento.

A arte gráfica mobilizou-se devido à situação de guerra. Em primeiro lugar, é importante lembrar, aqui, que as duas Grandes Guerras inspiraram muitas obras no campo das artes visuais. Inúmeras telas e esculturas foram produzidas em razão dos conflitos, seja através de pedidos 
oficiais dos governos, seja por protesto realizado pelos artistas. Pintores chegaram a deslocar-se para o front para documentar a realidade do conflito. Este tipo de trabalho era uma atividade patrocinada pelo governo, portanto, oficial.

Estas pinturas foram elaboradas dentro dos cânones da arte tradicional, figurativa, naturalista, de elementos românticos, neo-clássicos, combinados para suscitar, no espectador, sentimentos patrióticos e de solidariedade coletiva, além de repúdio ao inimigo.Esta arte tradicional também desempenha uma importante tarefa, a de glorificar e idealizar o passado das nações, através de imagens, personagens e cores que estabeleçam uma relação direta com este o passado. O caso da Alemanha merece destaque neste sentido:muitos de seus cartazes da Primeira Guerra são extremamente floreados, como se fossem pinturas feitas em cartazes; barrocos em seu exagero visual, apresentam o orgulho germânico por meio de cavaleiros, líderes e ideais do Reich.

A partir deste breve cenário descrito já nos é possível compreender que não existe campo favorável nesta "arte de guerra" para uma arte das vanguardas, para abstrações, para experimentações, existentes na pintura européia desde o final do século XIX e início do XX (e aqui, cabe lembrar as magníficas experiências feitas na cartazística russa com o uso da pintura, desenho e fotomontagem). Esta idéia também se reflete no cartaz de guerra, que, apesar de possuir uma grande diversidade visual, jamais ultrapassa os limites de uma estilização extrema, a ponto de dissolver as relações entre o significado, o signo e o significante.

Por mais econômica que seja a linguagem do cartaz (poucas palavras ou ausência das mesmas; uso de monocromia ou de, no máximo, duas cores contrastantes; destaque para apenas um único signo visual estilizado, como um fuzil ou um capacete, por exemplo), esta jamais deve ultrapassar o limite de um entendimento objetivo e preciso da mensagem. Em alguns momentos a intenção da mensagem parece ser dotada de tamanha urgência de transmissão e necessidade de entendimento pelo receptor que o uso de qualquer imagem no cartaz é dispensado. Esta é uma particularidade do cartaz: ele é livre para agregar imagem e palavra, bem como para escolher apenas uma ou outra. Esta característica de multiplicidade proporcionou a criação de milhares de cartazes diferentes, em um número bem superior ao das telas produzidas no período.

Partindo da observação de que a propaganda estimula e justifica o conflito, ao mesmo tempo em que exerce constantemente uma exaltação do nacionalismo, a construção visual do cartaz, as técnicas que utiliza, os 
personagens que apresenta, a mensagem que transmite por meio de suas imagens é algo que varia de nação para nação. Embora seja possível identificar particularidades sobre a produção dos cartazes em relação a cada país, também é possível identificar alguns aspectos comuns a esta estética: determinados elementos de iconografia que até então estavam restritos apenas ao campo da pintura, saem das telas e passam a integrar o novo suporte. Logo, o estilo dos cartazes deste período foi caracterizado, principalmente, por três fatores: o desenhista podia desenvolver o seu estilo pessoal (e neste sentido encontramos uma miríade de diversos estilos visuais nestes cartazes, sem a preocupação em obedecer um único código visual; observamos cartazes estilizados, a cores, em preto-e-branco, de inspiração barroca, neo-clássica, romântica, etc); o criador do cartaz podia lançar mão do imaginário nacional ou de um aspecto particular da História de sua nação (abre-se espaço, desta maneira, para a figura do herói nacional, que pode tanto ser anônimo - o soldado - como conhecido, um combatente de destaque que tenha participado de conflitos anteriores ou atuais); e por fim, o produtor do cartaz tinha a liberdade, se assim desejasse, de empregar estilos consagrados internacionalmente, como por exemplo, o Art Nouveau.

Estes elementos, aliados a outros, fazem do cartaz de guerra um aparato complexo, que pretende ser popular, possuir uma linguagem acessível (devemos lembrar que uma das grandes particularidades do cartaz é aliar a linguagem visual com a linguagem escrita, servindo-se de elementos como letras, números, símbolos), transmitir de maneira clara sentimentos de patriotismo, incentivar o alistamento, evitar o colapso das forças combatentes, desmoralizar o inimigo, encorajar uma nação. Embora esta propaganda tenha sido amplamente divulgada por intermédio de jornais, revistas, cartões postais, canções e até no cinema, o cartaz foi um dos meios mais populares, abrangentes e profundamente ligados ao espaço cotidiano do indivíduo em sua tarefa de divulgação de uma ideologia de guerra que continuaria, anos mais tarde, na Segunda Guerra Mundial. 


\section{Bibliografia}

BARNICOAT, John. Posters- a concise history. London: Thames and Hudson, 1994.

MOLES, Abraham. O Cartaæ: São Paulo: Perspectiva, 1987.

PHILIPPE, Robert. Affiches et caricatures dans l'histoire. Paris: Fernand Nathan Editeur, 1981.

Storia Illustrata della Prima Guerra Mondiale. Florença: Giunti, 1999. 